\title{
Metamorphic zircon-forming reactions and their use for tracking of metamorphic progression: an application to the eastern boundary of the Sveconorwegian Province
}

CINDY LIZETH URUEÑA AND CHARLOTTE MÖLLER

Lund University

Presenting Author: cindy.uruena@geol.lu.se

During metamorphism of igneous rocks such as gabbro, granite, and syenite, metamorphic recrystallization is largely steered by the influx of hydrous fluid and associated deformation. Where fluids were not introduced, rocks remain in a metastable igneous state. Low-silica rocks that contain primary baddeleyite (e.g., gabbro) preserve their baddeleyite in such metastable igneous states. Where hydrous fluid has been introduced, however, metamorphic reaction involving silica in solution has transformed igneous baddeleyite to metamorphic zircon [1]. This reaction can be used to date the metamorphic progression across metamorphic terranes and is particularly useful in large tracts of basement rocks.

We use the above relations to study the behaviour of the lower continental crust, here applied to the Eastern Segment (ES) in SW Sweden that underwent metamorphism during Sveconorwegian continental collision at $\sim 1 \mathrm{Ga}$. The ES exposes a coherent crustal portion $\sim 130 \mathrm{~km}$ wide which experienced tectonic burial to depths $\sim 40 \mathrm{~km}$. The setting has been compared to the Indian Lower Plate which is currently underthrusting Eurasia beneath the Himalaya [2].

The present textural-geochronological study includes undeformed and variably deformed varieties of a $1.2 \mathrm{Ga}$ metamorphosed syenitoid intrusion in a regional-scale $\mathrm{N}-\mathrm{S}$ trending steep deformation zone at the easternmost boundary of the Sveconorwegian Province. The well-preserved rock consists of igneous mesoperthite, orthopyroxene, minor biotite and apatite, and a range of accessory minerals including Fe-Ti oxides and baddeleyite. Micro-scale reaction textures are present also in the well-preserved rock: $<1 \mu \mathrm{m}$ wide zircon rims on baddeleyite, $\leq 50 \mu \mathrm{m}$ aggregates of polycrystalline zircon, and $10 \mu \mathrm{m}$ epidote grains. Intergrowths of titanite + zircon, and elongate titanite crystals with plenty of small zircon inclusions, represent pseudomorphs after a primary Ca-Zr-Ti-mineral, possibly zirconolite. The fully metamorphosed and undeformed equivalent contains feldspar, biotite, epidote, titanite and polycrystalline zircon pseudomorphs after baddeleyite. Metamorphosed and deformed varieties also contain garnet. U$\mathrm{Pb}$ analysis of metamorphic zircon will date metamorphism and deformation in the steep frontal deformation zone within basement, in the Sveconorwegian orogen.

[1] Beckman \& Möller (2018), J. Metamorph. Geol. 36, 12211236.

[2] Möller \& Andersson (2018), J. Metamorph. Geol. 36, 567589. 